
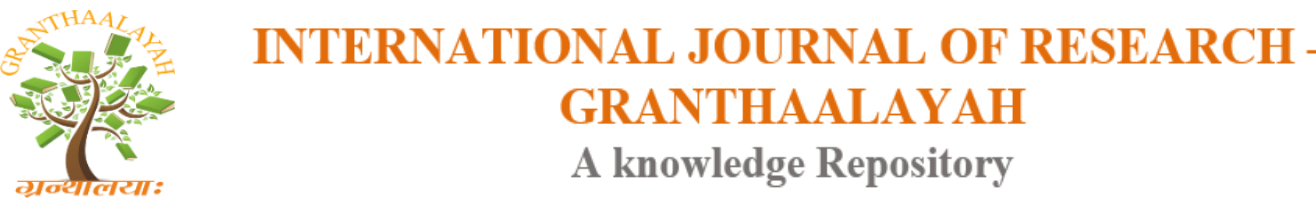

Science

\title{
COASTAL RESOURCE ENVIRONMENT PROFILE OF CATARMAN NORTHERN SAMAR
}

\author{
Myrna Nicol Ogoc *1 \\ ${ }^{* 1}$ Professor/Director, Center for Environmental Studies and Advocacy (CESA), University of \\ Eastern Philippines, Catarman N. Samar
}

\begin{abstract}
The coastline of the municipality of Catarman, Northern Samar stretches about 13.32 kilometers and its municipal waters has an estimated area of 66.304 square kilometers. Generally it has a plain bottom topography, consisting of coarse sand and muddy terrigenous soil that is carried and deposited by the fresh water that gush out from Catarman River, the major tributary of 'sweet water' which enriched the substrate with nutrients that eventually give rise to algal and plankton blooms that invite schooling pelagic fishes jacking up the commercial value of the municipal water. The soft bottom sediment gently slopes on the average of 3 degrees from the intertidal zone and stretches up to 60 meters deep seaward.

The municipality has an estimated aggregate coral reef area of 2,558 square meters with only $20 \%$ live coral cover that is mostly concentrated at the seaward side of reef edge, and with massive coral as its dominant life-form structure.

The death of coral reefs ( 60 percent of the cover) is generally presumed to be an aftermath of heavy siltation that is brought about by the influx of fresh water from Catarman river and other tributaries as evidenced by the brownish color of the silted coral heads. However, sites of coral rubbles (about $10 \%$ ) believed to be a remnant of the blast fishing in the area had been noticed. Non-biodegradable Solid wastes such as cellophanes and plastics were also observed neck-tied on some coral heads. Most of the fishes observed within 1-4 depth range along UEP- Cawayan Fringing reef and Puputihon patch reef are non-commercial reef fish species, such as Palata, Gono, Alibang-bang, lubayan while those fish species that are most preferred by fishermen are in least abundance and can only be observed at greater depth range (Molmol, Baraka, Mayamaya). Commonly, the sizes of the reef fish that were observed ranges from 6- 30 centimeters fork length suggesting that the fish stock in the area is still young. The volume of the fish stock within the reef system of Puputihon and UEP-Cawayan area is estimated to be at 15 kilograms per hectare. The high importance value of the" non-target" reef species connotes that the surrounding reef habitat has still the capability to carry out the necessary ecological processes of reef fish reproduction.

There are 5 species of seagrasses that thrives in Puputihon islet and UEP-Cawayan fringing reef. Ecologically, these seagrass areas serve as breeding and feeding grounds for some seagrassspecific fishes and mollusks. The Turtle Grass, Thallassia Hemprichii and Cymodocea sp.dominates the seagrass community (constituting about $85 \%$ of the area). The Eel grass (Enhalus acoroides), Spoon Grass (Halophila sp.), Needle Grass (Halodule sp.) are noted to be less occurring. Though, this macrophyte community could well serve the reef system ecologically
\end{abstract}


because of its high diversity, its environmental importance is not much due to its negligible area. Approximately, the seagrass community cover an aggregate of 500 square meter.

Of the twenty one (21) species of marine algae, ten (10) of which are chlorophytes or green algae, (four) 4 phaeophytes, brown algae and Seven (7) Rhodophytes or algae that gives off red color. Only Gelidiella acerosa, a Rhodophyte and Caulerpa spp.a chlorophyte are harvested by the fisherfolks for commercial purpose. Gelidiella acerosa or gulaman dagat have a density of 98.9 square meters per hectare during the conduct of the survey.

There are about 37 species of mollusks that are present along the UEP-Cawayan sampling sites, most of which are considered for commerce and domestic food.

Findings revealed the species composition of mangroves in all sampling stations. There were seven (7) families, nine (9) genera, comprising fifteen (15) species of true mangroves that are found in sampling stations. A total of 654 number of individuals were identified, counted, and measured. According to number of individual (ni), api-api (Avicennia officinalis) of the family Avicenniaceae registered to be the most abundant among other species and present in all sampling stations followed by bakauan-lalake (Rhizophora apiculata) and bakauan-babae (Rhizophora mucronata) of the family Rhizophoraceae with 73 and 66 number of individuals, respectively. The least encountered species were tangal (Ceriops tagal) and pototat (Bruguiera sexangula) with 2 and 1 number of individuals, respectively.

Keywords: Hydrobiological; Coastal Zone; Mangrove Swamp; Seagrass Beds; Algal Communities; Scattered Coral Heads.

Cite This Article: Myrna Nicol Ogoc. (2018). "COASTAL RESOURCE ENVIRONMENT PROFILE OF CATARMAN NORTHERN SAMAR." International Journal of Research Granthaalayah, 6(12), 196-208. https://doi.org/10.29121/granthaalayah.v6.i12.2018.1108.

\section{Introduction}

The compilation of this profile for the coastal area of the municipality of Catarman is one of the steps taken by the Local Government Unit of the municipality being spearheaded by the Department of Agriculture and the Bureau of Fisheries and Aquatic Resources in its aim to mitigate and control the persistent identified problems of the Municipal fishery and Agricultural council members and in the formulation of a CRM plan. The profile provides detailed background information and baseline data on the Catarman Coastal Zone and the local government units (LGUs) in the profile area. It provides broad information on the physical features, natural resources specifically the different coastal and marine resources, and the prevailing issues and opportunities. Information was based on various sources, primarily from secondary published and unpublished literature, including the Participatory Coastal Resource Assessments (PCRA), as well as interviews with key players in the crafting of this profile.

\section{Objectives}

The objective of this study was to make a Coastal Resource Ecological Assessment of the municipality of Catarman, Northern Samar which would provide some preliminary information on coastal and marine resources including its vegetation as an important refuge for marine and coastal organisms. The study team surveyed approximately the coastal plains which included areas from 
Tamburusan to UEP White beach including its tributaries. Since very little time was available and due to unfavorable weather condition especially at the onset of the assessment, and the area is so large, rapid assessment techniques were used during the survey which nevertheless provided sufficient data.

The consultancy team was commissioned by the Department of Agriculture Office and its Municipal Fishery and Agricultural council as part of the DA-BFAR Program in order to establish data base on their coastal resources that will serve as information guide in crafting and in the formulation of the Catarman Municipal Fishery Ordinance that seeks to conserve and use its marine and coastal resources sustainably.

\section{Methodology}

\subsection{Coral Cover}

\subsubsection{Swim-Through Survey}

Considering the prevailing weather condition of the last quarter of the year is not suitable for a Manta Tow Survey, a rigorous swim-through ocular assessment is opted in the conduct of Rapid Environmental Assessment of the area. Series of swim- survey at the drop-off, parallel to the reef crest has been done to capture the entire sampling area. The survey utilizes the variables used in the Manta Tow Survey to determine the 'health status' of the coral communities, to wit: Percent Live coral cover, percent dead coral cover, rubbles, sand and soft corals.

These variables are recorded into data sheets in categorical values:

$\begin{array}{ll}\text { Category } & \text { Percent Cover } \\ 1 & 0-10 \% \\ 2 & 11-30 \% \\ 3 & 31-50 \% \\ 4 & 51-75 \% \\ 5 & 76-100 \%\end{array}$

Cloud cover, water visibility, wave height, water depth, current direction and anthropogenic effects on corals are also noted during the conduct of the survey.

\subsubsection{Line Intercept Transect}

In the selected representative sites, based on the swim-through survey result, a more focused resource assessment methodology, the Line intercept Transect (LIT) technique is employed in gathering the quantitative description of the coral communities using its life-form categories. According to English (1990), these life-form categories are the minimum requirements for data base exchange among research institutions worldwide.

The LIT technique is used to estimate the cover of an object, based on its structural attributes or life-form rather on taxonomic level, within a specified area by calculating the fraction of the length of the line as intercepted by the object (Gates ,1979). The measure of cover, usually expressed as 
percentages is considered as an unbiased estimate of the proportion of the total area covered by the object, McIntyre (1953), Lucas\& Seber(1977), and Mundy(1991).

\subsection{Fishes}

\subsubsection{Rapid Fish Visual Census}

This method is used to determine species diversity. This is useful to determine which species to include in long-term monitoring.

\section{Method Description}

A swim survey is done at a constant speed for a fixed time instead of measuring the area with transect tapes. The method is useful to estimate relative abundance and is based on the assumption that the probability of encountering a species increases with its abundance. Therefore, the more common the species, the sooner the observer is likely to encounter it.

\section{General Procedures}

The observer swims randomly around a reef to locate and record as many fish species as possible; The swim is limited to the specific habitat (depth, reef zone) to determine species richness; Species are only recorded once when first seen in the specific 10 minute time interval, for a total of five 10 minute intervals. The 10 minute search intervals allows the observer to obtain estimates of the relative abundance of each species in addition to presence or absence data derived from the species lists. The assumption is that the species occurring in early time intervals are the most abundant in the community; Fishes occurring in the first 10 minute interval receive a score of 5, those in the second interval 4, and so on with the fifth interval fish scoring 1. Species scores are summed to indicate frequency of occurrence.

Jones and Thompson (1978); Kimmel (1985).

\subsubsection{Fish Stock Assessment}

Data from the fish visual census were collated and treated with the Length-weight relationship formula of $\mathrm{W}=\mathrm{a} \cdot \mathrm{L}^{\mathrm{b}}$ to come up with an estimated value of fish biomass per unit area. The parameters $a$ and $b$ were estimated through logarithmic transformation,i.e., $L n W=\ln a+b \ln L$ where $\mathrm{a}$ and $\mathrm{b}$ by ordinary least squares regression; $\mathrm{L}$ and $\mathrm{W}$ are length in $\mathrm{cm}$ and weight in grams respectively.

\subsubsection{Marine Molluscs}

Dartnall and Jones Transect line plot method (1986) was used to determine the density of mollusks species. Transect lines were established in the study sites from the upper coral reef margin to the seaward side. Sampling plots with an area of $10 \mathrm{~m} \mathrm{X} 10 \mathrm{~m}$ is laid along the line at an interval of $20 \mathrm{~m}$, all mollusks species will be recorded, counted and identified. 


\subsubsection{Marine Macrophytes}

In a Rapid Ecological Assessment where time is a constraint, plant species composition is most often sampled using the Braun-Blanquett method which involves identifying a specific area (called a "plot" or "quadrat"), identifying all species represented in that area, then assigning each a code based on its contribution to the total area. An example of Braun-Blanquet codes is:

0 : species not present 1: species $<5 \%$ of total 2: species $=5-10 \%$ of total 3: species $=10-25 \%$ of total 4: species $=25-50 \%$ of total 5 : species $=50-90 \%$ of total

\section{Results and Discussions}

Fringing coral reefs occurs throughout Catarman coastline, coexisted with other ecological systems such as the mangrove forest, seagrass and algal communities, and sand beaches. These interspersed diverse natural habitats had traditionally served as an invaluable resource for food for the coastal human settlement of the municipality.

The reef flat of the Catarman coast is of variable width, consisted of sand, rubbles, rocks, mangrove swamp, seagrass beds, algal communities, and scattered coral heads. Usually, every four (4) to (6) hours reef flats are submerged due to influx of tidal water. The outer edge of the reef flat, the reef crest is often the most biologically diverse and productive zone being exposed to waves, currents, and clean seawater.

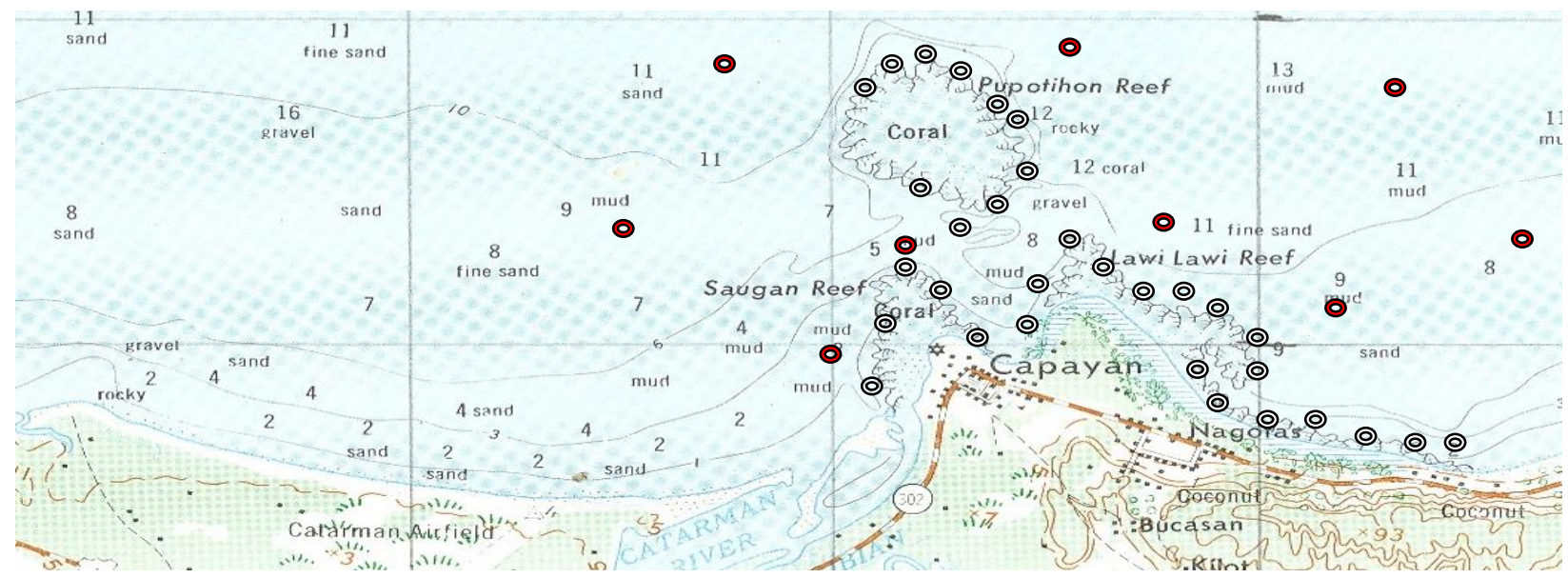

Figure 1: Sampling points at UEP-Cawayan Fringing reef and Puputihon Patch reef

Note: white dots are the sampling stations, from right to left direction. Dots in red are collection points for substrate samples.

\subsection{Relative Coral Cover}

With the swim-through survey conducted last November, 2011 along the reef crest that stretches from UEP White Beach to Parola, Cawayan more than half (60) \% of the total coral cover are observed to be in advanced state of destruction with only about 20 percent of the coral cover is alive, that is with coral polyps that exude lively colors. The condition ranges from sites with coral heads that are broken down to rubbles, about $10 \%$ of the entire area (that could be assumed as an 
evidence of dynamite or blast fishing in the recent past ) to areas which has standing but dead coral heads engulfed by algae or simply dead white in color (60\%),probably due to high siltation rate, turbidity and low salinity associated with areas adjacent to river mouth.

Fronting Sitio Cataogan of Brgy. Cawayan, approximately a kilometer away from the shore stands a patch reef (Puputihon reef) with an average depth of 20 meters. It supports a reef community with a relative live coral cover of about 40 percent. The live coral cover is extensive at its northern side being exposed to the interchange of cool clear waters from the open sea and the warm nutritious water from the coastal zone. The reef islet and the surrounding sub tidal patch reef could comprise about some square kilometers of potential site for a marine sanctuary zone establishment.

\subsubsection{Coral Life Forms}

Corals along UEP-Cawayan and Puputihon reef occurs mostly in massive forms, which accounts to 13.79 meters of the live corals along UEP- Cawayan area and 11.62 meters at Puputihon reef. Branching, Tabulate and Foliaceous coral occur less, and can only be found at depth of about 3 meters sub-tidally. Fragments of coral rubbles and solid wastes were also observed which connotes high environmental pressures and stresses to the living coral ecosystem of the area.

\subsubsection{Reef Associated Fishes}

Within 10 minute observation dives repeated 5 times in 3 different schedules, 15 families of 19 fish species with 101 individuals were recorded in the 2 sampling areas, the UEP-Cawayan fringing reef and the Puputihon patch reef. The most common fish that were noted occurring in the first 10 minute dive were non-target species or the fish species that are least preferred by fishermen due to their small sizes (e.g., Chaetodontids or Palata,Labriids or Lubayan, Pomacantiids or Alibang-bang). The high importance value of the aforementioned fish species indicates that though fishing pressure is high in the area due to the fewer occurrences of the "target fish species", the area is still ecologically rich enough to accommodate the presence of these "non target" fish species, an indication of the relatively healthy status of the habitat. Commercial Fish species which were in least abundance were observed at greater depths (5 meters and below), e.g. Scariids (Molmol), Acanthuriids (Surahan), Groupers (Baraka) and others.

Based on the data gathered, the Ichthyofaunal biomass around Puputihon patch reef and UEP Cawayan fringing reef at 1-4 meters depth range is estimated to be at $15 \mathrm{~kg}$ per ha. The data range comprises the fish species that were observed within 1- 4 meters depth only due to the limited water visibility during the time of sampling. Though the data gathered might not depict the true picture of the fish stock in the area due to the lacking data set for the fish species inhabiting the greater depths (depth range 4-10 m), yet the fish species observed could be considered as major contributors to the total fish stock in the area as implied by its dominant share in the fish catch of the resource users from the nearby fishing communities of So. Cataogan, and Parola of Brgy. Cawayan, Catarman, Northern Samar. 


\subsubsection{Marine Macrophytes}

There are about 5 seagrass species that are present in the sampling sites. Ecologically, seagrass areas serves as breeding and feeding grounds for some seagrass- specific fishes and mollusks. The Turtle Grass,Thallassia Hemprichii and Cymodocea sp.dominates the seagrass community (constituting about $85 \%$ of the area). The Eel grass (Enhalus acoroides), Spoon Grass (Halophila sp.), Needle Grass (Halodule sp.) are noted to be less occurring.

Padina sp., Sargassum sp., Chlorodesmis fastigiata,Enteromorpha intestinalis and some chlorophytes are noted in the sampling sites. Algal species are scarce due to low salinity in the intertidal zone as affected by the heavy monsoonal rains.

Although Marine algae had been a significant part of the country's economy (of which high economic contribution comes from the culture of Kappaphycus \& Eucheuma spp.) In Catarman, only Gelidiella acerosa (Gulaman) and Caulerpa sp. (Lato) are recognized by fisher folks to have direct economic value, thus harvesting is only focused on this two macrophyte species. On a modest observation, Gelidiella acerosa occur at UEP-Cawayan fringing reef at 98.9 square meter per hectare,during the November,2011- March 2012 survey.

\subsubsection{Marine Invertebrates}

Numerous commercial and food species of marine organisms are present in the UEP-Cawayan and Puputihon reef which renders the site as gleaning and fishing ground for the nearby coastal barangays.

According to some gleaners/fisher folks, at present the reef can still accommodate the daily protein needs of the adjacent coastal community if only regulations would be strictly imposed in relation to the prohibition of gill nets with small mesh sizes, use of poison/obnoxious substances, dynamite and coral quarrying which are still practiced by some individuals in the area.

\subsubsection{Hydrological Observations}

The survey was conducted coinciding the heavy influence of the northeast monsoon (Amihan) to the coastal waters of Catarman, Northern Samar which carries the characteristics of turbid, wavy and cold waters. This is the time when fisher folks ceased to become full-time fishers and shift their livelihood activities into other alternative income- generating ventures such as driving PD cabs, palay harvesting, domestic/construction helpers and others.

With the constant downpour of rain water brought about by the wind blowing from the pacific, heavy siltation is observed along the coast as evidenced by the influx of brownish freshwater from Catarman River and other tributaries. This explains the existence of only a reef-base but absence of living corals polyps on the periphery of the river mouth at So. Parola, Brgy. Cawayan and the presence of the dark- colored beach sand lining the northern edge of the municipality. The terrestrial sediments carried by the riverine waters are deposited as nutritious substrate in the shallow waters of the coast which give rise to the seasonal blooms of planktons, an invaluable feedstuff for schooling pelagic fishes which attract incidentally the commercial "Hulbot-hulbot" 
fishers to occasionally encroach the shallow waters of the municipality in anticipation of a richer catch.

Cloud cover is about 8 oktas, water visibility is very poor, $<1$ meter, wave height: $1-3$ meters.

\subsubsection{Bottom Topography}

Generally, the municipal waters of Catarman has plain bottom topography, from the intertidal zone, the sea bed gently slopes down on the average by $3^{\circ}$ up to about 60 meters depth seaward which is consisted of terrigenous materials ranging from coarse sand to sandy muddy substrate.

\subsubsection{Mangrove Assessment}

Catarman is blessed with mangrove forests around its offshore areas, river systems and estuaries. The municipality has a biologically diverse mangrove ecosystem with seven (7) families, nine (9) genera and fifteen (15) "true" mangrove species found on its shores.

Out of 54 species of true mangroves (34 major and 20 minor) and 60 mangrove associates throughout the whole world, the Philippines has around 47 "true mangroves" and associated species belonging to 26 families. True mangrove species are those that strictly grow in the mangrove environment while associated species may thrive on other habitat types such as beach forest and lowland areas.

Mangroves are critical spawning, nursery, feeding and transient shelter areas to hundreds of fish species, crustaceans and invertebrates and support an abundant and productive marine life.

Like all other animals, fish, shrimp, crab and other marine life in the sea need a safe place to grow, away from any predator. With their tangles and intricate root systems, mangroves are excellent nurseries, providing safe hiding places for young animals. The muddy waters around them are rich in nutrients from decaying leaves and organic matter produced by the mangroves themselves and also from the sediments that is trapped around the roots.

Many commercial marine species such as bangus (milkfish) and prawns spend their early life within the mangrove area where they find food and protection from predators. Juveniles of some deep sea fishes also spend some time in the mangroves before moving on to other ecosystems such as sea grasses and coral reefs.

Actual data gathering was conducted with a team of expert from the DENR, BFAR, the academe and the Northern Samar Environmental Protectors (NSEP) Inc. Catarman mangroves are characterized as second growth forest situated in the shoreline of Brgy. UEP Zone 1, UEP Zone 2, So. Cataogan, Brgy. Cawayan and in Taguibi-an river systems and its estuary.

\subsection{Mangrove Assessment Methology}

Transect line plot method with $10 \mathrm{~m} \times 10 \mathrm{~m}$ quadrat is being employed to gather data on mangrove community structure. Number and species of mangrove trees encountered were counted, 
identified, measured and recorded. Measurements includes height and crown cover of each trees. In every quadrats, three (3) sub-quadrats of 1x1 meter were laid in every 10x10 meter quadrat for the determination and counting of seedlings and saplings.

\subsection{Species Composition, Distribution, and Abundance}

In order to acquire reliable data on species composition, distribution and abundance of mangroves, the assessment team utilized five sampling stations with 14 transect line and 44 quadrats. Transect lines was purposively laid down from landward through seaward in the area with 1 to 4 quadrats in each transect line depending on the abundance of mangrove vegetations.

Succeeding table shows the species composition and abundance of mangroves by transects lines that are found in every sampling station in the area together with their coordinates and locations. Summary table shows the species composition of mangroves in all sampling stations. There were seven (7) families, nine (9) genera, comprising fifteen (15) species of true mangroves that are found in sampling stations. A total of 654 number of individuals were identified, counted, and measured. According to number of individual (ni), api-api (Avicennia officinalis) of the family Avicenniaceae registered to be the most abundant among other species and present in all sampling stations followed by bakauan-lalake (Rhizophora apiculata) and bakauan-babae (Rhizophora mucronata) of the family Rhizophoraceae with 73 and 66 number of individuals, respectively. The least encountered species were tangal (Ceriops tagal) and pototat (Bruguiera sexangula) with 2 and 1 number of individuals, respectively.

\subsection{Crown Diameter and Percent Crown Cover}

The highest crown diameter observed was in Station 5 with a total crown diameter of 319.1 with average crown cover of 1.47 . The total crown diameter was $1,118.74$ and with an average crown cover of 1.71 .

\subsection{Tree Height and Average Height}

As revealed in Table 17, the highest average height observed was in Station 1 with 3.56 meters while the lowest was 1.94 in Station 4. The average height of all trees counted was 2.61 meters, which is considered in fair condition and proportionate to the average crown cover of 1.71 meters.

\subsection{Species Density and Relative Density}

The total density and relative density of trees in the study area. On a per hectare basis, stem density of the major tree species in Catarman showed that api-api/miyapi (Avicennia oficinalis) has the highest density of 788 trees per hectare with a relative density of 53.05 percent while bakauan lalake (Rhizophora apiculata) had density of 166 with relative density of 11.16 percent ranked second followed by Bakauan babae (Rhizophora muncronata) with a density 150 and relative density of 10.09 respectively. The highest density of api-api/miyapi (Avicennia oficinalis) under the family Avicenniaceae could be due to the favorable soil substrate and other environmental factors that favored its growth compared to other tree species present in the study area. 


\subsection{Frequency and Relative Frequency}

Frequency is the number of times the species present in the area. As revealed in Table 19, the species that possessed the highest frequency of all species was api-api/miyapi (Avicennia oficinallis), Bakauan lalaki (Rhizophora apiculata) and Bakauan babae (Rhizophora muncronata) having a frequencies of 1 with relative frequency of 14.03 percent. This implies that the above cited species are present in all quadrats in all sampling stations. This further implies that the soil/substrate and other environmental conditions in the area could probably favored the growth and multiplication of these species compared to other tree species observed in the area.

\section{Summary of Findings}

Based on the results of the survey, it was found out that:

The coastline of the municipality of Catarman, Northern Samar stretches about 13.32 kilometers and its municipal waters has an estimated area of 66.304 square kilometers. Generally it has a plain bottom topography, consisting of coarse sand and muddy terrigenous soil that is carried and deposited by the fresh water that gush out from Catarman River, the major tributary of 'sweet water' which enriched the substrate with nutrients that eventually give rise to algal and plankton blooms that invite schooling pelagic fishes jacking up the commercial value of the municipal water. The soft bottom sediment gently slopes on the average of 3 degrees from the intertidal zone and stretches up to 60 meters deep seaward.

The municipality has an estimated aggregate coral reef area of 2,558 square meters with only $20 \%$ live coral cover that is mostly concentrated at the seaward side of reef edge, and with massive coral as its dominant life-form structure.

The death of coral reefs ( 60 percent of the cover) is generally presumed to be an aftermath of heavy siltation that is brought about by the influx of fresh water from Catarman river and other tributaries as evidenced by the brownish color of the silted coral heads. However, sites of coral rubbles (about $10 \%$ ) believed to be a remnant of the blast fishing in the area had been noticed. Non-biodegradable Solid wastes such as cellophanes and plastics were also observed neck-tied on some coral heads. Most of the fishes observed within 1-4 depth range along UEP- Cawayan Fringing reef and Puputihon patch reef are non-commercial reef fish species, such as Palata, Gono, Alibang-bang, lubayan while those fish species that are most preferred by fishermen are in least abundance and can only be observed at greater depth range (Molmol, Baraka, Mayamaya). Commonly, the sizes of the reef fish that were observed ranges from 6- 30 centimeters fork length suggesting that the fish stock in the area is still young. The volume of the fish stock within the reef system of Puputihon and UEP-Cawayan area is estimated to be at 15 kilograms per hectare. The high importance value of the" non-target" reef species connotes that the surrounding reef habitat has still the capability to carry out the necessary ecological processes of

\subsection{Reef Fish Reproduction}

There are 5 species of seagrasses that thrives in Puputihon islet and UEP-Cawayan fringing reef. Ecologically, these seagrass areas serve as breeding and feeding grounds for some seagrass- 
specific fishes and mollusks. The Turtle Grass, Thallassia Hemprichii and Cymodocea sp.dominates the seagrass community (constituting about $85 \%$ of the area). The Eel grass (Enhalus acoroides), Spoon Grass (Halophila sp.), Needle Grass (Halodule sp.) are noted to be less occurring. Though, this macrophyte community could well serve the reef system ecologically because of its high diversity, its environmental importance is not much due to its negligible area. Approximately, the seagrass community cover an aggregate of 500 square meter.

Of the twenty one (21) species of marine algae, ten (10) of which are chlorophytes or green algae, (four)4 phaeophytes, brown algae and Seven (7) Rhodophytes or algae that gives off red color. Only Gelidiella acerosa, a Rhodophyte and Caulerpa spp.a chlorophyte are harvested by the fisherfolks for commercial purpose. Gelidiella acerosa or gulaman dagat have a density of 98.9 square meters per hectare during the conduct of the survey.

There are about 37 species of mollusks that are present along the UEP- Cawayan sampling sites, most of which are considered for commerce and domestic food.

Findings revealed the species composition of mangroves in all sampling stations. There were seven (7) families, nine (9) genera, comprising fifteen (15) species of true mangroves that are found in sampling stations. A total of 654 number of individuals were identified, counted, and measured. According to number of individual (ni), api-api (Avicennia officinalis) of the family Avicenniaceae registered to be the most abundant among other species and present in all sampling stations followed by bakauan-lalake (Rhizophora apiculata) and bakauan-babae (Rhizophora mucronata) of the family Rhizophoraceae with 73 and 66 number of individuals, respectively. The least encountered species were tangal (Ceriops tagal) and pototat (Bruguiera sexangula) with 2 and 1 number of individuals, respectively.

\subsection{The Need for Coastal Resource Management}

Coastal resource management $(\mathrm{CRM})$ is the identification of holistic and appropriate human interventions (a combination of social, technical and scientific strategies) through participative efforts to manage the use of coastal resources in a sustainable manner. CRM aims primarily to involve and consider the welfare of the affected communities along with other stakeholders in every stage of the undertaking, for a sustained coastal and marine environment and improved quality of life. CRM tries to focus its activities on the short-term needs of the communities vis-àvis the long-term issues and resolve such needs and issues. Coastal resource use issues in the province of Northern Samar particularly Catarman that can be addressed by CRM include:

- Continued treatment of the coastal resources as an open access resource, with only limited management and "ownership" being applied

- Continued over-fishing and destruction of the coastal resources

- Inequitable distribution of fishery benefits, with very limited individuals (financiers, illegal

- fishers and commercial fishers) getting the major share of the resource at the loss of the small-scale fishers (95\% of the total number of fishers)

- Lack of information, education and communication (IEC) on and enforcement of coastal laws by multi-sector coastal law enforcement groups 
- Lack of coordination, collaboration and common direction among the NGAs, NGOs, LGUs and coastal communities

- Many jurisdictional issues and gray areas still have to be resolved by and among NGAs, LGUs (provincial, municipal), NGOs and communities, with some not taking responsibility of their jurisdictional mandates amid lack of coordinated planning between these agencies

- Poor land and coastal resource uses as well as a lack of framework for decision making for LGUs to better manage the resources

- Pollution, runoff and siltation from upland areas due to poor and inappropriate human practices.

\section{Recommendations}

Based on the findings, it could be assumed that the fishery resources of the municipality cannot cope up with the growing protein demand of the populace if no environmental rehabilitation/protection measures will be employed. One of the potential strategy is for the municipality to establish a marine protective area were fishing activities are regulated so as to give the existing marine resources to reproduce up to its optimum capacity. One of the productive zone in terms of fishery resource that needs 'recovery period' from resource extraction is the area surrounding Puputihon reef and UEP- Cawayan reef system.

CRM Benchmarks for Local Government Units must be made:

- Budget allocated for CRM

- Multi-year CRM Plan drafted (5 years)

- Appropriate CRM best practices planned and initiated

- MFARMC strong and active

- Multi-year CRM Plan finalized and adopted

- Municipal ordinance supports plan/CRM code

- At least two CRM best practices implemented

- Coastal law enforcement effective

- Financial and human resources assigned permanently to CRM activities.

- -Sustained long-term implementation of CRM with monitoring, measured results and positive returns

- -Bio-physical improvement in resources measured (i.e. increase in coral cover or fish abundance)

- Socio-economic benefits accrued to coastal residents (i.e. actual increase in livelihood within the communities), incorporating the profile of the fisherfolks;

- Illegal activities totally minimized

- Annual budget based on results of monitoring and Municipal Coastal Database

The TWG will also provide assistance and training in participatory monitoring and evaluation to coastal LGUs interested in applying for CRM certification. Coastal municipalities interested in CRM-certification must follow the "Guidelines for Monitoring and Evaluation of CRM Plans and Programs for CRM Certification" which describes the process and benchmarks for CRM certification. 
Information Management: The Key to Successful Implementation.

\section{Acknowledgement}

Acknowledgement is being extended to the DENR and UEP Team who made this study a success and the funding support extended by the Local Government of Catarman.

\section{References}

[1] English, S., C. Wilkinson, and V. Baker, "Transect Line Plot Method". Survey Manual for Tropical Marine Resources: (Australian Institute of Marine Science, P.M.B. No. 3. Townsville Mail Center, Australia, 1994).

[2] Lucas and Seber (1977) Derived unbiased estimators for density, D, and percentage cover, C, for any spatial distribution. https://journals.uair.arizona.edu/index.php/jrm/article/viewFile/.

[3] Jones and Thompson, 1978; Kimmel, 1985. A new species-time method for visual assessment of fishes and its comparison with established methods. Environmental Biology of Fishes; January 1985, Volume 12, Issue 1, pp 23-32.

[4] Douglas A. Wikum; G. Frederick Shanholtzer, July 1978, Volume 2, Issue 4, pp 323-329 |

[5] Application of the Braun-Blanquet cover-abundance scale for vegetation analysis in land development studies, Environmental Management.

*Corresponding author.

E-mail address: myrna_uep@yahoo.com 